九州大学学術情報リポジトリ

Kyushu University Institutional Repository

\title{
Current State and Trends in Forest Management in Cambodia
}

Sokh, Heng

Laboratory of Forest Resources Management, Division of Forest Ecosphere Sciences and Management, Department of Forest and Forest Products Sciences, Graduate School of Bioresource and Bioenvironmental Sciecnes, Kyushu University

Iida, Shigeru

Laboratory of Forest Resources Management, Division of Forest Ecosphere Sciences and

Management, Department of Forest and Forest Products Sciences, Faculty of Agriculture, Kyushu University

https://doi.org/10.5109/24475

出版情報: 九州大学大学院農学研究院紀要. 47 (1)，pp. 233-241，2002-10-30. Kyushu University バージョン：

権利関係 : 


\title{
Current State and Trends in Forest Management in Cambodia
}

\section{Heng SOKH* and Shigeru IIDA}

\author{
Laboratory of Forest Resource Management, Division of Forest Ecosphere Sciences and Management, \\ Department of Forest and Forest Product Sciences, Faculty of Agriculture, Kyushu University \\ 394, Tsubakuro, Sasaguri-machi, Fukuoka-ken, Japan 811-2415 \\ (Received June 28, 2002 and accepted July 12, 2002)
}

\begin{abstract}
While forest resources in Cambodia have been decreasing rapidly in the last few decades, a great deal of attention is being given at present to the idea of community forests. This study tried to investigate the current change of forest management with a special reference to the present trends in community forestry development in Cambodia. Forest resources are a central part of livelihood of many local communities in Cambodia. The forest laws that came to be applied in the last few decades alienated local communities' rights to claim ownership of forests. This has resulted in a huge loss of forest resources and a poor national environment, threatening the subsistent livelihoods of the rural poor. The apparent growing interest in community forestry in Cambodia in the last decade has opened a new page of forest management. We are convinced that community forestry will become an integral part of sustainable forest management in Cambodia. While, at present, community forestry is still at the initial stage, there is a demand for more experiments and trials to test a variety of manifestation of the concept. In order to achieve a successful community forestry development, learning from both successes and failures of the current community forestry implementation is vital.
\end{abstract}

\section{INTRODUCTION}

More than $80 \%$ of Cambodia's population live in rural areas whose livelihoods depend on agriculture, fisheries and forest products. Timber and non-timber forest products such as rattan, bamboo, resins and forest foods are essential to the life of many rural communities. In addition, flooded and mangrove forests provides important habitats for fisheries and marine resources. Fifty percents of the total population depend on these resources for their daily protein needs and consumption. Likewise, forests in the uplands play a key role in conserving soil and ensuring water flow, which are crucial for irrigation systems and agricultural activities throughout the country. Nevertheless, the government of Cambodia has granted more than seven million hectares of mainly well-stocked forest areas as concession forests to develop large scale forest industry and improve national income. However, this forest management system has proved little success in term of economic return to the country while resulted in dramatic decrease of forest cover and threatened well-being of the rural communities (Global Witness). While understanding of Cambodia's forest sector has grown over the past several years, there are still considerable uncertainties about potential, conditions of forest resource and trends in forest management. This study aims to determine the current state of forest resources and the

\footnotetext{
* Laboratory of Forest Resource Management, Division of Forest Ecosphere Sciences and Management, Department of Forests and Forest Product Sciences, Graduate School of Bioresource and Bioenvironmental Sciences, Kyushu University Forests
} 
challenges faced in seeking to achieve sustainable forest management in Cambodia. It is anticipated that the findings of the study will contribute to decision-making and policy debates at both national and local levels.

\section{METHODS}

The study has been designed to provide a descriptive picture of forest conditions and recent trend in forest management in Cambodia. Information for this study mainly was obtained through formal and informal interviews with officials the Forestry Department, provincial forestry offices. Documentary research data were collected from various sources including the Forestry Department in Phnom Penh, non-government office representatives and other research institutions in Cambodia. The study was also relied upon research papers, books, reports, document from a variety of sources. In addition, two field observations to the community forestry project sites were planned and conducted. One was in Takeo province where first community forestry project in Cambodia was developed. Another was in Siam Reap province where the number of community forestry projects has remarkably increased. During these two field observations, semi-structured interviews were carried out with projects staff and a number of project participants. The objectives were to obtain empirical information on community forestry project implementation in the areas and to investigate the potential of community-based forest management in general. All information and data collected for this study were analyzed quantitatively and qualitatively by using simple descriptive statistics analysis techniques.

\section{RESULTS}

\section{Geographical and socioeconomic conditions}

Located in Southeast Asia, the country of Cambodia covers a total area of 181,035 square kilometers between $10^{\circ}$ and $15^{\circ}$ north latitude and $102^{\circ}$ and $108^{\circ}$ east longitude in the tropical north. The neighboring countries include Vietname to the east and south, Laos to the north, Thailand to the west and the Gulf of Thailand to the southwest. Topographical conditions in Cambodia can be divided into three distinct parts: the central plain dominated by the basin of the Great Lake, the Caramon mountains in the southwest and along the coast, and the undulating plateau in the east where elevation ranges from 100 to 300 meters.

Since 1989, economic reforms have changed the system from a centrally planned to market economy. The introduction of private ownership of land has had a direct impact on forest resources and rural economy. The majority of Cambodian people are farmers living in rural areas with production of food and cash crops as their main occupation. Many of them depend on forests for their subsistent needs because the soil is low in fertility and the climatic conditions do not support good agricultural productivity. The annual average income per capita is US\$150-200.

\section{Land use}

Cambodia's land use and forest resources have passed through dramatic change in the past few decades. Table 1 interprets a significant land cover change between 1973 and 
1993. The most significant changes can be observed on cropping lands, forest lands, shrubland and abandoned land. There were significant decreases in dry land forest (down 1.1 million ha) and edaphic forest (down 316,900 ha). In sum, the rate of deforestation during this period was in excess of 70,000 ha/year. This figure reflects a conversion of forest to agricultural land use, but a significant proportion of forest area was so severely degraded and should be re-classified as shrublands rather than forests (FAO 1997). Between 1993 and 1997, a further 700,000 hectares of deforestation occurred, 345,000 ha being classified into shrublands and a similar amount converted to agriculture land. The rate of deforestation accelerated to over $180,000 \mathrm{ha} / \mathrm{year}$ as a result of greater harvesting pressure from loggers and local communities (FAO 1997).

Table 1. Land use pattern in Cambodia, 1973-1993

\begin{tabular}{lcccc}
\hline Type & $\begin{array}{c}\text { Area in 1973 } \\
(1,000 \mathrm{ha})\end{array}$ & $\begin{array}{c}\text { Area in 1993 } \\
(1,000 \mathrm{ha})\end{array}$ & $\begin{array}{c}\text { Change } \\
(\%)\end{array}$ & $\begin{array}{c}\text { Annual } \\
\text { change (\%) }\end{array}$ \\
\hline Urban & 14.7 & 4.5 & -69.4 & -3.5 \\
Rice fields & 2,521 & 2,639 & 4.7 & 0.2 \\
Other crops & 582 & $1,275.4$ & 119.1 & 6.0 \\
Dry land forests & $11,678.6$ & $10,568.6$ & -9.5 & -0.5 \\
Edaphic forests & $1,032.5$ & 715.6 & -30.7 & -1.5 \\
Shrublands & $1,056.9$ & $2,260.6$ & 113.9 & 5.7 \\
Abandoned lands & 786.3 & 278.7 & -64.6 & -3.2 \\
Water surface & 481.5 & 411.1 & -14.6 & -0.7 \\
\hline Total & $18,153.5$ & $18,153.5$ & - & - \\
\hline
\end{tabular}

Source: Land Use Mapping Office, MAFF

The most significant changes of land cover occurred mainly on cropping lands in the last decade. About a 119\% increase in cropping lands and a $114 \%$ increase in shrublands have been observed. In contrast, dry land forests and edaphic forests have decreased about $9.5 \%$ and $30.7 \%$, respectively (Table 1 and Fig. 1).

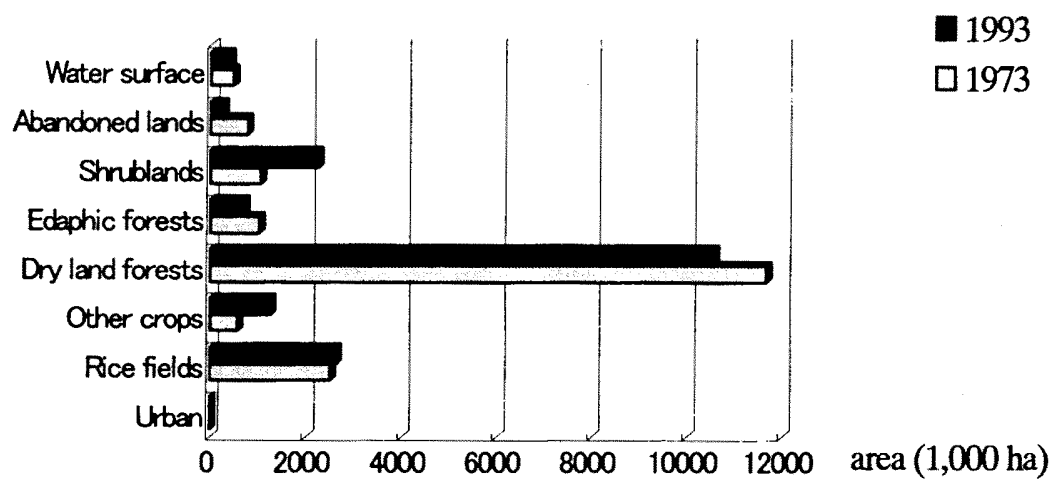

Fig. 1. Change in land use pattern, 1973-1993 


\section{Forest types and potential}

Table 2 and Fig. 2 show the areas of each forest type in Cambodia. According to the Forestry Department's classification, there are two main forest types: Evergreen and Deciduous forests. The Evergreen forests fall mainly into the disturbed category in which illegal and poorly controlled logging have taken place. The main species are Dipterocarpus dyeri, D. corbatus, D. Alalatus, Anisoptera cochinchinensis, Hopea adorata, H. pierrei, Roherea vulgaris, and Syzygium sp. Deciduous forests cover about $21 \%$ of the total land area (DFW, 1998).

As can be seen in Table 2, Evergreen and Deciduous forests account for nearly all of the forest areas. Of this, the Deciduous forest has limited commercial potential. Of the Evergreen forests, the great bulk is disturbed, and it is here that the worst excesses of illegal and poorly control logging have taken place. Assuming the area of Evergreen forest could be reasonably well distributed and its regeneration potential protected, the total area of approximately 4 million hectares with a growth of approximately 0.3 cubic meters per hectare per year would yield an allowable cut in the range of 1 to 1.2 million $\mathrm{m}^{3}$. If, however, as appears to be the case, uncontrolled logging has significantly disrupted the structure of the forest and delayed regeneration, a sustainable yield could be significantly lower and probably in the range of 500,000 to 1 million $\mathrm{m}^{3}$ annually.

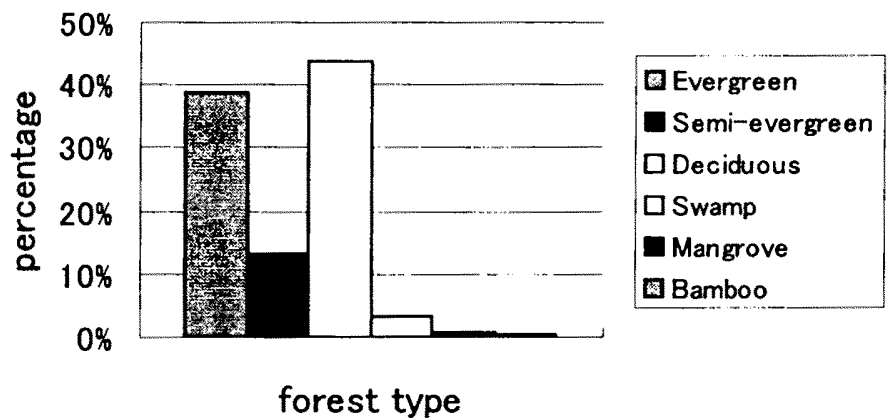

Fig. 2. Forest types in Cambodia, 1997

Table 2. Forest type and forest cover in Cambodia, 1997

\begin{tabular}{lrrr}
\hline Forest type & Area (ha) & Forest Area (\%) & Land Area (\%) \\
\hline Evergreen & $4,094,028$ & $38.9 \%$ & $22.6 \%$ \\
Semi-evergreen & $1,394,436$ & $13.2 \%$ & $7.7 \%$ \\
Deciduous & $4,597,009$ & $43.6 \%$ & $25.4 \%$ \\
Swamp & 351,206 & $3.3 \%$ & $1.9 \%$ \\
Mangrove & 77,260 & $0.7 \%$ & $0.4 \%$ \\
Bamboo & 21,823 & $0.2 \%$ & $0.1 \%$ \\
\hline Total & $10,535,762$ & $100.0 \%$ & $58.2 \%$ \\
\hline
\end{tabular}

Source: Forestry Department, MAFF 


\section{Forest policy and regulation}

Cambodia's forest legislation (Forestry Decree 1985) regulates the commercial use of forest resources. It requires sustainable yield management and the protection of residual stands from logging damage. These and other guidelines, though they require updating, are generally credible and could protect the forest if they were effectively implemented. In 2000, a Forest Development Plan was planned and approved. Main forest policy objectives as stated in this Forestry Development Plan, 1997-2000, include:

a). to manage the forest resource on a sustainable basis for the continuous production of forest goods and services and their optimum utilization, compatible with environmental requirement;

b). to establish forest plantation of both indigenous and exotic species with emphasis on fast growing species and to promote multiple use forestry and environmental conservation;

c). to conserve and protect the forest's biological diversity, water and soil and their sustainable use;

d). to strengthen human resource development to support the forestry sector

However, a notable problem of forestry policy at present seems to be the lack of political will to enforce regulations. In fact, the FD has been excluded from the process of awarding concessions and other important decision, which are typically approved by senior government officials. In addition, its shortage of qualified staff, equipment, and vehicles limits its ability to assess timber stocks in proposed concession areas, and makes it difficult to monitor violation of contract agreement and other forestry activities throughout the country.

\section{Reforestation}

Reforestation plantation achievements by the FD totaled 5,470 hectares until 1972. This comprised of Pinus (225 ha), Eucalyptus (24ha), Tectona (2,136 ha) and deciduous species (3,085 ha). From the period 1972-84 there was no reforestation due to political, economic, and social reforms under the Khmer Rouge and the early years under the Vietnamese government. Since 1985 the FD has planted an additional 2,000 hectares of Acasia auriculiformis, Eucalyptus camaldulensis, Tectona grandis and Pinus merkusii plantations. However due to poor care, low survival, incidences of fire and theft, it is unlikely that this total area remains intact.

\section{Economic importance of forest resources}

Forest resources are very important to Cambodia's economy. According to the report by the World Bank, earnings from the forest sector accounted for 12 percent of total national budget and 1.3 percent of Cambodia's gross domestic product (GDP) in both 1994 and 1995. These figures have since dropped to 2.8 percent of the national budget and 0.3 percent of GDP in 1996 (Table 3). Reports from observers familiar with Cambodian forestry suggest that the decline in revenue collections does not reflect a true reduction (Jim, 1998). This is due to uncontrolled and illegal harvests. It is estimated that at harvest rate in the 1990s, Cambodia's forest resources may be economically depleted in the early years of the twenty-first century. This may result in severe political and economic 
disruption (World Bank 1996)

Based on the estimated sustainable timber yield for Cambodia ( 0.5 to 1.5 million cubic meters per year) and the current royalty rate structure (US\$14 per cubic meter for the most timber), the forest sector could sustainable yield US\$7-21 million per year. However, it is believed that these figures underestimate the potential of Cambodia's forest. resources. Evidence suggests that the royalty can be increased to US $\$ 25$ per cubic meter in the short-run and still allow for a reasonable return on investment, thereby increasing royalties to US $\$ 12.5$ to US $\$ 37.5$ million per year (World Bank 1999).

Table 3. Forest sector's contribution to the government revenues

\begin{tabular}{cccc}
\hline Year & $\begin{array}{c}\text { Forest revenue } \\
\text { (riel million) }\end{array}$ & $\begin{array}{c}\text { National } \\
\text { budget share (\%) }\end{array}$ & $\begin{array}{c}\text { Revenue as } \\
\text { share of GDP(\%) }\end{array}$ \\
\hline 1992 & 1,400 & 0.9 & 0.1 \\
1993 & 3,800 & 1.3 & 0.1 \\
1994 & 86,000 & 14.6 & 1.4 \\
1995 & 85,900 & 12.4 & 1.2 \\
1996 & 22,500 & 2.8 & 0.3 \\
\hline
\end{tabular}

Source: Forestry Department, MAFF

In Cambodia, where income opportunities are scarce, forests have served as an employer and financier for many years. They have also provided critical sources of rural income. If Cambodia's forests are economically depleted, these potential benefits will be lost. In addition, it will have significant environmental impacts. These include the loss of watershed protection as well as a reduction of biological diversity and climate control.

\section{Recent trends in forest management}

Current status: A number of recent initiatives in community-based forest management are underway in Cambodia. Most of the initiatives emphasize developing pilot examples and models of community forestry in specific target areas. These initiatives have been highly beneficial in promoting and demonstrating community forestry, and in encouraging favorable policy. Some of these initiatives also support institutional strengthening associated with pilot efforts, although generally this is treated as a relative minor objective.

Two national ministries, the Ministry of Environment (MoE) and the Ministry of Agriculture, Fisheries and Forestry (MAFF) have recognized responsibilities for community forestry, and each has established a Community Forestry Unit (CFU). Although national policies and responsibilities for community forestry remain unclear, senior officials of both the MoE and the FD have expressed support for community forestry programming, for strengthening staff and institutional capacities, and for cooperation. Provincial governments also seem eager to promote community forestry within their territories. Although the lack of clear national policy raises uncertainty for provincial governments, several provincial forestry and/or environmental departments have established 
community forestry programs, and several others have expressed a desire to start community forestry.

Most of community forestry projects in Cambodia are implemented based on financial and technical supports from various international and non-government organizations. $\mathrm{MCC}$, a non-government organization with collaboration with the FD, set up the first pilot project in Takeo province in 1994. The project initially involved 12 villages with 500 ha of degraded land for community forestry activities (Butterfield, 1998). Recently, it has expanded to include six other neighboring villages (Sokh, 2000). It is believed that, up to now, there are hundreds of community forestry projects under planning and implementing throughout the country. In Siam Reap province alone there are 33 community forestry projects covering a total of 276,800 ha with a total population of more than 340,000 . Most of these projects began in 1995 by the FAO with funding from the Belgium Government (FAO, 1999).

Constraints in community forestry development: As previously noted, the government policy toward community forestry is not clear. The government officials and agencies have extensively allocated forest resources in ways that effectively deny local communities from the use or benefits of forest resources, irrespective of customary uses and needs. This expresses government unconcern with local community dependence on or management of forests. Some government officials have also stated that community forestry is appropriate for degraded forests but not for non-degraded forests, which suggests a policy of denying benefit while transferring costs to local communities, a policy which wide experience demonstrates will fail.

Most staff responsible for community forestry programs received extremely limited training in community forestry concepts and methods. Of all the staff who have received training, their skill levels in applying concepts and methods are low and very few staff have field experience with community forestry (Henderson, 1998).

In addition, some community forestry programs have been underway without any monitoring and evaluation on their impacts on the welfare of the society. This has resulted in a lack of documentation and information on community forestry in Cambodia.

\section{DISCUSSIONS}

The deforestation and destruction of forest resources have become a major problem for many countries. In Cambodia, the short-term need for economic benefits drew the government to make many logging concessions (Phin, 1994). The rapid decrease of forest resources in Cambodia has resulted in a poor national environment threatening the subsistent livelihoods of the rural poor.

In many countries, community forestry have proved successful in bring about sustainable forest management (Sokh, 2001). In Cambodia, public awareness of problems caused by forest deforestation has been increasing. It is observed that forest management in Cambodia has arrived at the crossroad between a complete deforestation and a sustainable forest management. Handing out forests to the local communities for community forestry development is believed to be one of the best options for sustainable forest management in Cambodia. 
While enabling policies and laws would promote and accelerate community forestry, the lack of specific policy has not posed a significant impediment to community forestry proposal and activities to date in Cambodia. The support for community forestry by two Ministries, the MAFF and the MoE, and a number of provincial governments, in cooperation with international organizations (IOs) and non-government organizations (NGOs), as discussed above, establishes a general policy climate favorable to continuing and expanding community forestry. Several NGOs and the Food and Agriculture Organization (FAO) are actively working at the field level on community forestry initiatives and are assisting the FD and other ministries with training and capacity building. Yet, the FD is currently preparing a draft Community Forestry Sub-decree that would authorize individuals or associations to access and use forest lands by entering into contractual arrangements with the government.

Based on an earlier estimation, perhaps 4 million ha of relatively high potential forests is available for commercial production and some 3.3 million hectares is currently devoted to protection status. There still remain approximately 3 million hectares of forest and another 7 million ha of rural area in which management of small forest areas and scattered trees is needed. In these areas, community forestry can play a very important role in conserving the remaining forests. In addition to having the potential for poverty alleviation, community forestry needs to be recognized as a means for achieving sustainable management for the large bulk of forest resources that are not suited to commercial production and which will be beyond the direct management capacity of the government.

\section{CONCLUSIONS}

The data presented in this study shows how seriously conditions in forestry in Cambodia had deteriorated, especially during the last few decades. Illegal logging has reached alarming level and local people are being negatively affected by the current operation of massive concession forests. This prospect is threatening both the forest industries investors who face a lack of log supply and the local communities who face hardship in deriving a livelihood from the same forests.

Forestry can become an integral part of the overall development of Cambodia if all forests are to be properly managed and exploited. Within this regard, more and more people now believe that a sustainably managed forest sector in Cambodia can only be built based on a substantially stronger local community involvement.

Based on the results of this study, we are convinced that community forestry is going to play a central role in reforestation and prevention of further deforestation if properly applied. However, many challenges and difficulties remained. At this critical stage of decentralization of forest management, foresters and researchers should study to find appropriate strategies of this community-based forest management system in order to develop and implement it effectively all over the country. In addition, training of forestry officials and development workers to support and facilitate the process of community development is essential. Such training should emphasize sociological aspects and reorient working style from being authoritarian and directive to a more incentive, farmers and participatory approach.

While there are many variations on what constitutes community forestry, however, it 
also broadly calls for the creation of research framework to bridge the gap of knowledge on local participation in the management of forest resources.

\section{REFERENCES}

DFW 1998 Forest cover statistics in Cambodia. Department of Forest and Wildlife, Pnhom Penh, Cambodia, 208pp

Butterfield, R. 1998 Community livelihoods and common property resources in Cambodia. Technical paper No. 6. Associate in Rural Development (ARD, Inc.), Phnom Penh, Cambodia, 26pp

DFW 1996 Forestry Development Plan, 1997-2000. Department of Forest and Wildlife, Pnhom Penh, Cambodia, 58pp

FAO 1999 Participatory natural resource management in the Tonle Sap region, GCP/CMB/002/BEL, Siam Reap, Cambodia

Henderson, D., 1998 Community forestry in Cambodia. Department of Forest and Wildlife, Pnhom Penh, Cambodia, $11 \mathrm{pp}$

Jim, C. 1998 Reforestation and natural forest rehabilition policy in Cambodia. Technical Paper No. 3, Associate in Rural Development (ARD, Inc.), Phnom Penh, Cambodia. 35pp

Phin, S. 1994 Deforestation in Cambodia. Master thesis, Khon Kaen University, Bangkok, Thailand, pp. $145-170$

Sokh, H., K. Yukutake, and A. Yoshimoto 2000 Farmers' perspective on community forestry in Cambodia: A case study of the Banteay Angkor Community Forestry Program, Takeo province, Bull. Kyushu Branch of J. Jpn. For. Soc., 53: 5-8

Sokh, H. and S. Iida 2001 Community forestry models in southeast Asia and Cambodia: A comparative study. J. Fac. Agr., Kyushu Unv., 46: 113-121

World Bank 1996 Forest policy assessment, Phnom Penh, Cambodia, 60pp

World Bank 1999 A vision for forestry sector development, Background note, Cambodia consultative group meeting, Phnom Penh, Cambodia, 28pp 